\title{
Clinical analyses of successful and previously failed intracytoplasmic sperm injection cycle parameters in patients with poor ovarian reserve
}

\section{Düşük over rezervli olgularda başarılı ve başarısız siklusların klinik analizi}

\author{
Tayfun Kutlu, Enis Özkaya, Pınar Kumru, Habibe Ayvacı, Belgin Devranoğlu, İlhan Sanverdi, Yavuz Şahin, \\ Beyhan Sağlam, Ateş Karateke
}

Zeynep Kamil Maternity and Children's Health Training and Research Hospital, Clinic of Obstetrics and Gynecology, İstanbul, Turkey

\begin{abstract}
Objective: To determine some major characteristic differences between two consecutive successful and unsuccessful intracytoplasmic sperm injection (ICSI) cycles in poor responders.

Materials and Methods: Sixty women with poor ovarian response as determined using the Bologna criteria underwent ICSI cycles following an unsuccessful trial. Some parameters of both cycles including age, body mass index (BMI), serum follicle-stimulating hormone (FSH) and estradiol levels, antral follicle count, gonadotropin dosage, duration of stimulation, antagonist starting day, duration of antagonist administration, endometrial thickness at trigger day, number of total and fertilized oocytes, embryo transfer day, number of embryo cells, and fertilization rate were compared in the same patients to identify predictors of cycles with clinical pregnancy.

Results: The mean age, BMI, serum FSH, estradiol concentrations, and antral follicle count were 35.9 years (range, $30-42$ years), $25.9 \mathrm{~kg} / \mathrm{m}^{2}$ (range, $18.4-33.5 \mathrm{~kg} / \mathrm{m}^{2}$ ), $10.9 \mathrm{IU} / \mathrm{mL}$ (range, $7-13 \mathrm{IU} / \mathrm{mL}$ ), $52.9 \mathrm{pg} / \mathrm{mL}$ (range, 11.6-75 pg/mL), and 4.7 (range, 2-10), respectively. A comparison of cycle characteristics showed a significantly higher total number of mature and fertilized oocytes in successful cycles. The fertilization rate was also significantly higher in cycles with clinical pregnancy. Early initiation of antagonist was shown to result in favorable outcomes. A comparison of embryo characteristics showed that transfer of higher-stage embryos and embryos with higher numbers of cells had a significant impact on cycle outcomes.

Conclusion: Our comparison of parameters of failed and successful ICSI cycles in poor responders revealed significantly earlier antagonist initiation, higher total number of mature and fertilized oocytes, fertilization rate, and significantly higher stage of embryo development and cell numbers at transfer in cycles that resulted in clinical pregnancy.
\end{abstract}

Keywords: Poor responders, assisted reproduction, fertilization rate, gonadotropin-releasing hormone antagonist

$\ddot{\mathrm{O} z}$

Amaç: Zayıf cevaplı hastalarda birbirini takip eden başarılı ve başarısız intrasitoplazmik sperm enjeksiyonu (ICSI) sikluslarında bazı majör özellik farklarının ortaya konmasıdır.

Gereç ve Yöntemler: Bologna kriterlerine göre karar verilmiş 60 düşük yanıtlı hasta başarısız bir siklus sonrası ICSI tedavine alındı. Başarılı ve başarısız sikluslarda yaş, vücut kitle indeksi (VKİ), serum folikül stimülan hormon (FSH) ve estradiol düzeyleri, antral folikül sayısı, gonadotropin dozu, stimülasyon, antagonist başlama günü, antagonist uygulama süresi, tetikleme günü endometrial kalınlık, total ve fertilize oosit sayısı, embriyo transfer günü, embriyo hücre sayısı ve fertilizasyon oranlarını içeren değişkenler aynı hasta grubunda klinik gebeliği öngörmek üzere karşılaştırıldı.

Bulgular: Ortalama yaş, VKİ, serum FSH, estradiol düzeyleri ve antral folikül sayısı sırası ile 35,9 (30-42 yll), 25,9 (18,4-33,5 kg/m²), 10,9 (7-13), 52,9 (11,6-75 pg/mL), 4,7 (2-10) idi. Bazı siklus özelliklerinin karşılaştırılmasında, başarılı siklusta daha fazla total, matür ve fertilize oosit sayısı izlendi. Klinik gebeliğin olduğu siklusta fertilizasyon oranı daha yüksekti. Antagoniste erken başlamak daha iyi sonuçla ilişkili idi. Bazı embriyo özelliklerinin karşılaştırılmasında, ileri evredeki ve daha fazla sayıda hücreli embriyo transferinin sonuca anlamlı etkisi olduğu izlendi.

Sonuç: Düşük over yanıtlı hastalarda başarılı ve başarısız siklusların karşılaştırlması klinik gebelik olan siklusta erken antagonist başlanması, yüksek sayıda total, matür ve fertilize oosit sayısı, fertilizasyon oranı, daha ileri evre ve daha fazla hücreli embriyonun transferi ile sonuçlanmıştır.

Anahtar Kelimeler: Zayıf cevaplı hasta, yardımla üreme, fertilizasyon oranı, gonadotropin salgılatıcı hormon antagonisti

Address for Correspondence/Yazışma Adresi: Enis Özkaya, MD,

Zeynep Kamil Maternity and Children's Health Training and Research Hospital, Clinic of Obstetrics and Gynecology, İstanbul, Turkey

Phone: +902163910680 E-mail: enozkaya1979@gmail.com

Received/Geliș Tarihi: 01.11.2016 Accepted/Kabul Tarihi: 15.01.2017

${ }^{\oplus}$ Copyright 2017 by Turkish Society of Obstetrics and Gynecology

Turkish Journal of Obstetrics and Gynecology published by Galenos Publishing House 


\section{Introduction}

Women prefer to postpone their pregnancy plans to older ages due to career concerns(1-3). Consequently, these women face a high risk of failure at conceiving in spontaneous cycles and seek assisted reproduction, especially in industrialized countries. This demand from health care providers leads to growing numbers of difficult infertile patients to be treated through assisted reproductive techniques. Moreover, these patients fail to respond to standard stimulation protocols due to poor ovarian reserve. The European Society of Human Reproduction and Embryology introduced the Bologna criteria in 2011 in order to standardize the definition of poor ovarian response(4). Some stimulation protocols modified with adjuvant therapies and increased gonadotropin doses were tried to obtain favorable outcomes in poor responders(5). In a study on the association between the number of eggs and live birth, the number of eggs in in vitro fertilization (IVF) was accepted to be an indirect indicator for clinical success. Analyses of data revealed a non-linear relationship between the number of eggs and live birth rate following IVF treatment. The maximum live birth rates were obtained when approximately 15 eggs were retrieved(6). Harvesting of 4-6 oocytes has been defined to be poor response (7).

Several studies compared the cycle outcomes of gonadotropinreleasing hormone antagonist administration with flexible (according to follicular size) and fixed starting days. Metaanalyses on this issue revealed no statistically significant difference in pregnancy rate between flexible and fixed protocols. There was a statistically significant reduction in the amount of recombinant follicle-stimulating hormone (rFSH) with the flexible protocol(8).

An inter-cycle variability of responses to gonadotropin stimulation was shown in a recently published study. In the study, the authors categorized patients according to the number of follicles on the day of human chorionic gonadotropin (hCG) administration as low $(0-<6)$, normal $(6-<18)$, and high $(\geq 18)$, and showed that only $73.9 \%$ of patients remained in the same category after a new cycle(9).

In this study, we tried to determine some major characteristic differences between two consecutive successful and unsuccessful cycles in patients with poor ovarian response.

\section{Materials and Methods}

After approval of the hospital ethics committee, this retrospective study was conducted from January 2014 to December 2014 in the IVF/intracytoplasmic sperm injection (ICSI) unit of Zeynep Kamil Women and Children's Health Training and Research Hospital (approval number: 2014183). A total of 60 women with a failed and subsequent successful ICSI cycle were retrospectively screened from the hospital database and cycles with and without successful outcomes were compared in terms of cycle characteristics. In order to determine the minimum number of subjects needed to be enrolled in this study in order to have sufficient statistical power, sample size calculation was performed before the study. The probability of a type-1 error $(\alpha)$, a difference being found although a difference does not exist, was calculated. We used an alpha cut-off of 5\% (0.05). All participants had regular menstrual cycles, normal serum prolactin levels, and had not received hormone treatment in the last 3 months. The patients' ages ranged from 30 to 42 years.

All patients underwent assisted reproductive technology treatment because of their previous poor response and/or poor ovarian reserves. At least two of the following three criteria had to be fulfilled to establish the definition of poor ovarian reserve: (1) advanced maternal age (>40 years) or any other risk factor for poor ovarian response; (2) a previous poor ovarian response ( $\leq 3$ oocytes with a conventional stimulation protocol); (3) an abnormal ovarian reserve test [i.e. antral follicle count (AFC) less than 5-7 follicles or anti-Müllerian hormone below $0.5-1.1 \mathrm{ng} / \mathrm{mL}]$. Women whose cycles did not reach the embryo transfer stage, and those with endometriosis, male factor infertility, and previous ovarian surgery were excluded from the study.

An antagonist protocol was used in all patients for both cycles. On the second day of the menstrual cycle, depending on the patient's response, rFSH 300-450 IU were administered and follicular growth was monitored using transvaginal sonography. The dosage of $\mathrm{rFSH}$ was adjusted starting from day 5 of stimulation according to the ovarian response. Follicle monitorization was performed using two dimensional measurements of growing follicles and a calculation of the mean value at each visit.

Antagonist (Cetrorelix, Merck-Serono, Geneva, Switzerland) $0.25 \mathrm{mg} /$ day was administered when the follicular size was 12$14 \mathrm{~mm}$. After the follicular size reached $18 \mathrm{~mm}$, recombinant hCG $250 \mu \mathrm{g}$ was administered, and follicular puncture was performed after 34-36 hours. Next, the application of $8 \%$ vaginal progesterone gel twice/daily was started. The serum hCG level was measured 2 weeks later; if the serum hCG level was more than or equal to the normal level, ultrasonography was performed in the days following serum hCG level measurement to detect a fetal pulse to confirm clinical pregnancy.

Age, body mass index (BMI), serum FSH, estradiol, AFC, stimulation protocol, gonadotropin type and dosage, duration of stimulation, duration of antagonist administration, menstrual day at embryo transfer, embryo cell number, endometrial thickness at trigger day, total number of oocytes and fertilized oocytes and fertilization rates were compared between failed and successful consecutive trials with a maximum interval of 2 months.

Data were analyzed using SPSS 15.0 for Windows. The paired samples t-test was used to compare continuous variables between two separate cycles within the group. A p value $<0.05$ was accepted as statistically significant. 


\section{Results}

The mean age, BMI, FSH, estradiol concentrations, AFC were 35.9 years (range, 30-42 years), 25.9 (range, 18.4-33.5 kg/ $\mathrm{m}^{2}$ ), $10.9 \mathrm{IU} / \mathrm{mL}$ (range, 7-13 IU/mL), 52.9 (range, 11.6-75 pg/mL), 4.7 (range, 2-10) respectively (Table 1). A comparison of cycle characteristics showed a significantly higher total oocyte number and fertilized oocytes in successful cycles. The fertilization rate was also significantly higher in cycles with clinical pregnancy. Early initiation of antagonist was shown to result in favorable outcomes. A comparison of embryo characteristics showed that transfer of higher-stage embryos and embryos a higher number of cells had a significant impact on cycle outcomes. All comparisons of variables between the two cycles are summarized in Table 2.

\section{Discussion}

In this study, we assessed cycle characteristics in poor responders with and without successful clinical pregnancy such as age, BMI, serum FSH, estradiol, AFC, stimulation protocol, gonadotropin dosage, duration of stimulation, duration of antagonist administration, antagonist starting day, menstrual day at embryo transfer, embryo cell number, endometrial thickness at trigger day, number of total and fertilized oocyte and fertilization rates. Our data revealed that early initiation of antagonist, higher number of total, mature and fertilized oocyte number with higher fertilization rates and transferring significantly higher stage of embryo development and embryo cell numbers led to favorable outcomes in ICSI cycles.

Table 1. Summary of some demographic characteristics of study population

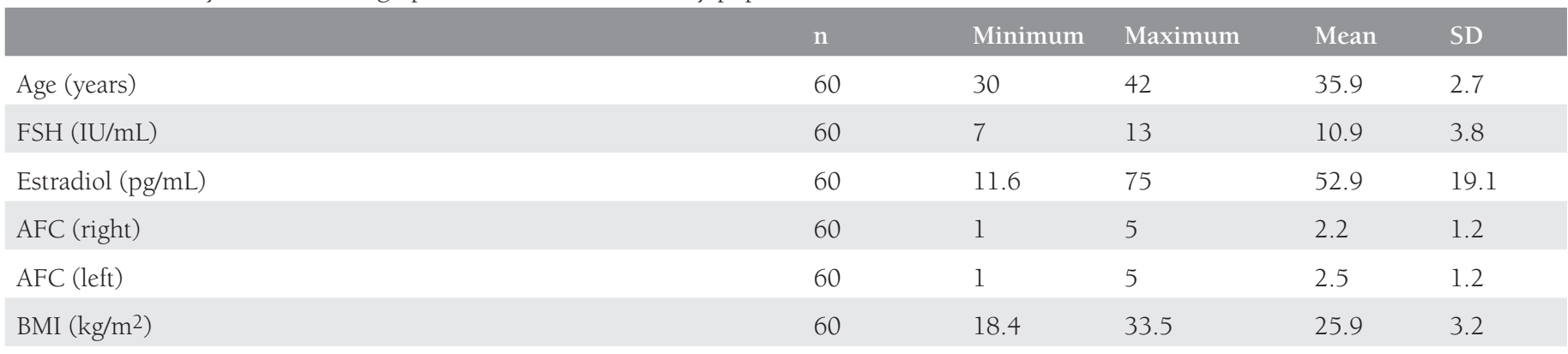

SD: Standard deviation, FSH: Follicle-stimulating hormone, AFC: Antral follicle count, BMI: Body mass index

Table 2. Comparison of some parameters of successful and preceding failed cycle in women with poor ovarian response

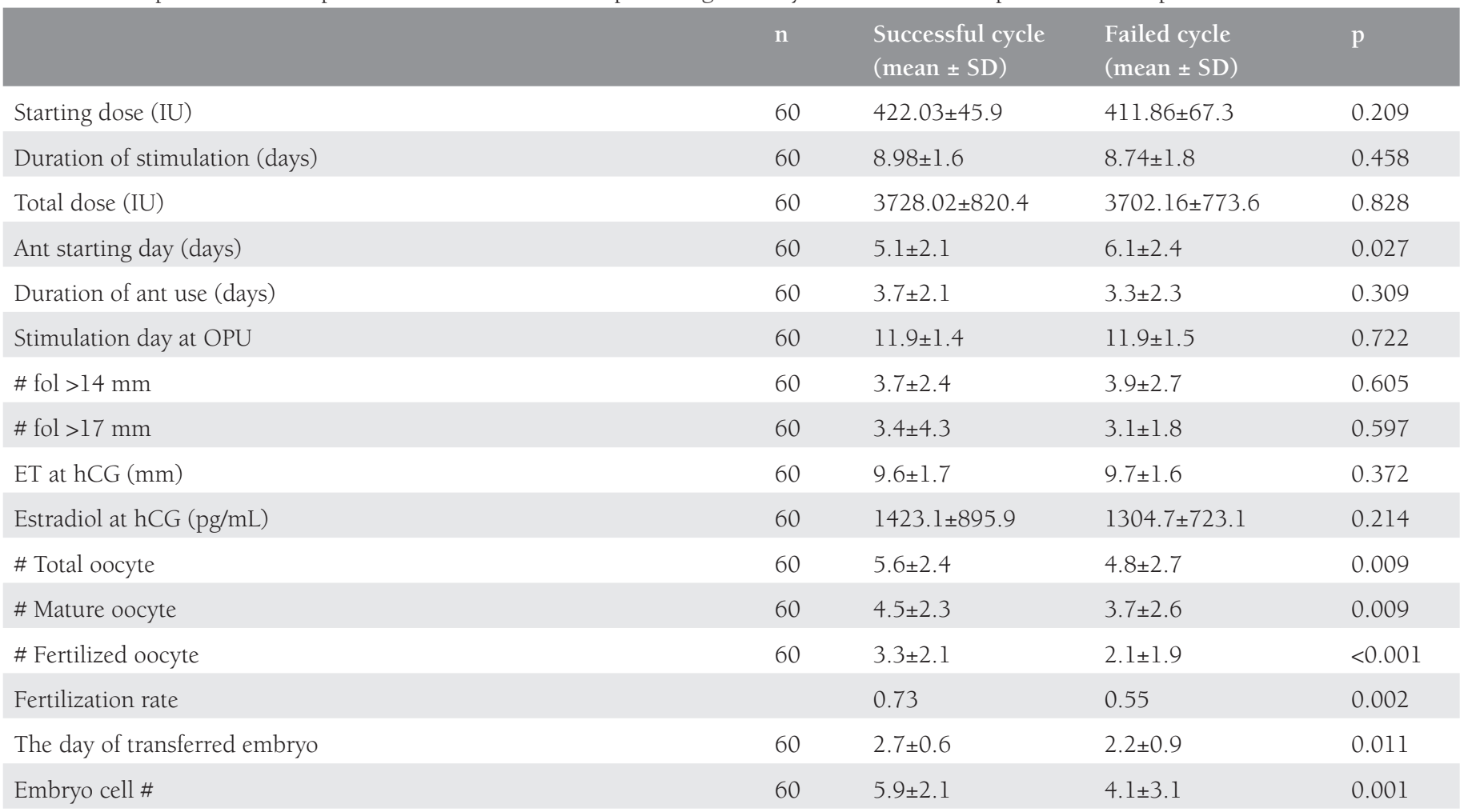

SD: Standard deviation, OPU: Oocyte pickup, Fol: Follicle, ET: Embryo transfer, hCG: Human chorionic gonadotropin 
Despite introduction of many protocols with different initial doses and types of gonadotropins, optimal management of patients who are poor responders is still a concern. In this study, we tried to identify characteristics of a successful cycle compared with a preceding failed cycle in the same patients with poor ovarian response. Most of the time, when responses to the standard dose of gonadotropins (225-300 IU) for a proper multifollicular growth fails, dose increments are attempted to obtain a better outcome. Therefore, high doses of gonadotropins were proposed for a couple of decades in poor responders. However, there are some conflicting data regarding the success of increased gonadotropin doses in the management of poor responders. Previous studies showed no enhanced ovarian response and/or better pregnancy rates when $450 \mathrm{U}$ of increased doses of gonadotropins were used(10-12). Furthermore, a recently published study indicated that an increased starting dose of FSH did not result in higher pregnancy rates, and outcomes were similar between groups with different gonadotropin starting doses (300 UI, 450 UI, and $600 \mathrm{UI}$ ) of gonadotropins with regard to retrieved oocytes, number of embryos obtained, and pregnancy rates(13). In our study, the mean starting and total gonadotropin doses were similar between the two cycles. However, we found significantly earlier antagonist initiation in successful cycles. The modified early antagonist start protocol was introduced to improve cycle outcomes. It was claimed that improved mature oocyte yield could be enhanced through follicular synchronization. Additionally, significantly higher clinical pregnancy rates compared with the conventional antagonist protocol were reported(14). Furthermore, delayed-start of antagonist protocol was proposed to result in favorable outcomes in terms of number of dominant follicles and mature oocytes retrieved, mature oocyte yield, and fertilization rates in poor responders. The authors concluded that this was the result of the promoting and synchronizing effect on follicle development without impairing oocyte developmental competence(15). Besides a higher rate of fertilization, we also found significantly higher numbers of total, mature oocyte and earlier antagonist initiation in successful cycles. Especially in patients with poor ovarian reserve, the number of oocytes has a critical role for cycle outcome. Studies on this issue showed a significant relationship between the number of eggs and live birth in all age groups. A study proposed that the number of eggs in IVF was an indirect indicator for clinical success. The best outcome was obtained when approximately 15 eggs were retrieved(6). However, a yield lower than 4-6 oocytes after stimulation has been considered to be poor response $(7)$. In our study, the mean total number of oocytes harvested during failed and successful cycles were 4.8 and 5.6, respectively. Although both results are within the range of the poor response definition, it seems that a minimal increase in total oocyte numbers with increased fertilization rates resulted in favorable outcomes.
Another factor is the fertilization rate, which was thought to be an indirect finding for oocyte quality and was shown to be a significant predictor for embryo implantation(16). Some morphologic characteristics of oocytes, such as zona pellucida thickness, cytoplasm appearance, and polar bodies were investigated to select the best embryos to transfer and therefore further minimize the number of embryos transferred(17-20). However, according to the accumulated data, most of these parameters had a minimal impact for this purpose (21,22). Embryo grading systems were developed and found correlated with pregnancy outcomes. Despite their limitations, grading systems are the most commonly applied procedures in the selection of the most qualified embryo for transfer. Further embryo assessments focused on the zygote stage, evaluation of embryo behavior at early cleavage, and extended culture performed to day 5 showed improved pregnancy outcomes $(23,24)$. There are also some data at the molecular level for implantation prediction (25). However, after adjustment of the aforementioned covariates, the fertilization rate was shown as a significant predictor for embryo implantation in a previous study(16). As mentioned above, our data also showed significantly increased fertilization rates in cycles with clinical pregnancy.

The relationship between embryo quality and pregnancy rates has been shown in several studies(26-28). Early cleaving 2-cell embryos have been shown to have higher pregnancy rates than patients without early-cleaving 2-cell embryos(29), and furthermore, transfer of 4-cell embryos resulted in significantly higher implantation and pregnancy rates compared with transfers of 2 and 3-cell embryos. Additionally, cell number was found as the strongest predictor of pregnancy in day 3 embryos in a scoring system based on cell number, fragmentation, and other morphologic criteria deemed specific to day 3 embryos(30-32). According to a Cochrane review, cumulative clinical pregnancy rates from cleavage stage resulted in higher clinical pregnancy rates than from blastocyst cycles(33). Data showed a decreased overall embryo quality score in embryos that were kept in culture till day 3(34). In our assisted reproductive technology clinic, we try to avoid keeping embryos in culture media for more than 3 days, except when the top quality embryo has not been determined. In majority of cases, we prefer 2 to 3-day embryo transfers, especially in the event of a low number of embryos. Our data showed that number of cells in 2 to 3-day embryo transfers had a critical role in ICSI cycles; the number of cells was significantly higher in cycles with clinical pregnancy (4.1 vs. 5.9, $\mathrm{p}<0.05)$.

\section{Conclusion}

Early initiation of antagonist, higher number of total, mature oocyte yield, higher fertilization rates and transfer of embryos with higher number of cells were significant factors of successful outcomes in poor responders. Further research on this topic should be conducted with larger study populations to elaborate 
on the implications of our study, and to obtain more data to modify cycles for better results in poor responders.

\section{Ethics}

Ethics Committee Approval: The study was approved by the Zeynep Kamil Women and Children's Health Training and Research Hospital Local Ethics Committee (Approval number: 2014-183), Informed Consent: Consent form was filled out by all participants.

Peer-review: Externally peer-reviewed.

\section{Authorship Contributions}

Surgical and Medical Practices: E.Ö., T.K., P.K., H.A., B.D., İ.S., Y.Ş., B.S., A.K., Concept: T.K., Design: T.K., Data Collection or Processing: E.Ö., T.K., P.K., H.A., B.D., İ.S., Y.Ş., B.S., A.K., Analysis or Interpretation: E.Ö., Literature Search: E.Ö., Writing: E.Ö., T.K.

Conflict of Interest: No conflict of interest was declared by the authors.

Financial Disclosure: The authors declared that this study received no financial support.

\section{References}

1. Matthews TJ, Hamilton BE. Delayed childbearing: more women are having their first child later in life. NCHS Data Brief 2009;21:1-8.

2. Leridon H, Slama R. The impact of a decline in fecundity and of pregnancy postponement on final number of children and demand for assisted reproduction technology. Hum Reprod 2008;23:1312-9.

3. Cabry R, Merviel P, Hazout A, Belloc S, Dalleac A, Copin H, et al. Management of infertility in women over 40. Maturitas 2014;78:1721.

4. Ferraretti AP, La Marca A, Fauser BC, Tarlatzis B, Nargund G, Gianaroli L, et al. ESHRE consensus on the definition of "poor response' to ovarian stimulation for in vitro fertilization: the Bologna criteria. Hum Reprod 2011;26:1616-24.

5. Ubaldi F, Vaiarelli A, D'Anna R, Rienzi L. Management of poor responders in IVF: is there anything new? Biomed Res Int 2014;2014:352098

6. Sunkara SK, Rittenberg V, Raine-Fenning N, Bhattacharya S, Zamora J, Coomarasamy A. Association between the number of eggs and live birth in IVF treatment: an analysis of 400135 treatment cycles. Hum Reprod 2011;26:1768-74.

7. Faber BM, Mayer J, Cox B, Jones D, Toner JP, Oehninger S, et al. Cessation of gonadotropin-releasing hormone agonist therapy combined with high-dose gonadotropin stimulation yields favorable pregnancy results in low responders. Fertil Steril 1998;69:826-30

8. Al-Inany H, Aboulghar MA, Mansour RT, Serour GI. Optimizing GnRH antagonist administration: meta-analysis of fixed versus flexible protocol. Reprod Biomed Online 2005;10:567-70.

9. Rombauts L, Lambalk CB, Schultze-Mosgau A, van Kuijk J, Verweij $\mathrm{P}$, Gates $\mathrm{D}$, et al. Intercycle variability of the ovarian response in patients undergoing repeated stimulation with corifollitropin alfa in a gonadotropin-releasing hormone antagonist protocol. Fertil Steril 2015;104:884-90.

10. Land JA, Yarmolinskaya MI, Dumoulin JC, Evers JL. High-dose human menopausal gonadotropin stimulation in poor responders does not improve in vitro fertilization outcome. Fertil Steril 1996;65:961-5
11. Karande VC, Jones GS, Veeck LL, Muasher SJ. Highdose folliclestimulating hormone stimulation at the onset of the menstrual cycle does not improve the in vitro fertilization outcome in low-responder patients. Fertil Steril 1990;53:486-9.

12. van Hooff MH, Alberda AT, Huisman GJ, Zeilmaker GH, Leerentveld RA. Doubling the human menopausal gonadotrophin dose in the course of an in-vitro fertilization treatment cycle in low responders: a randomized study. Human Reprod 1993;8:369-73.

13. Berkkanoglu M, Ozgur K. What is the optimum maximal gonadotropin dosage used in microdose flare-up cycles in poor responders? Fertil Steril 2010;94:662-5.

14. Park CW, Hwang YI, Koo HS, Kang IS, Yang KM, Song IO. Early gonadotropin-releasing hormone antagonist start improves follicular synchronization and pregnancy outcome as compared to the conventional antagonist protocol. Clin Exp Reprod Med 2014:41:158-64.

15. Cakmak H, Tran ND, Zamah AM, Cedars MI, Rosen MP. A novel "delayed start" protocol with gonadotropin-releasing hormone antagonist improves outcomes in poor responders. Fertil Steril 2014;101:1308-14.

16. Rosen MP, Shen S, Rinaudo PF, Huddleston HG, McCulloch CE, Cedars MI. Fertilization rate is an independent predictor of implantation rate. Fertil Steril 2010;94:1328-33.

17. GarsideWT, Loret de Mola JR, Bucci JA, Tureck RW, Heyner S. Sequential analysis of zona thickness during in vitro culture of human zygotes: correlation with embryo quality, age, and implantation. Mol Reprod Dev 1997;47:99-104

18. Hassan-Ali H, Hisham-Saleh A, El-Gezeiry D, Baghdady I, Ismaeil I, Mandelbaum J. Perivitelline space granularity: a sign of human menopausal gonadotrophin overdose in intracytoplasmic sperm injection. Hum Reprod 1998;13:3425-30.

19. Kahraman S, Yakin K, Dönmez E, Samli H, Bahçe M, Cengiz G, et al. Relationship between granular cytoplasm of oocytes and pregnancy outcome following intracytoplasmic sperminjection. Hum Reprod 2000;15:2390-3

20. Xia P. Intracytoplasmic sperm injection: correlation of oocyte grade based on polar body, perivitelline space and cytoplasmic inclusions with fertilization rate and embryo quality. Hum Reprod $1997 ; 12: 1750-5$

21. Balaban B, Urman B, Sertac A, Alatas C, Aksoy S, Mercan R. Oocyte morphology does not affect fertilization rate, embryo quality and implantation rate after intracytoplasmic sperm injection. Hum Reprod 1998;13:3431-3.

22. Ciotti PM, Notarangelo L, Morselli-Labate AM, Felletti V, Porcu E, Venturoli S. First polar body morphology before ICSI is not related to embryo quality or pregnancy rate. Hum Reprod 2004;19:2334-9.

23. Fisch JD, Rodriguez H, Ross R, Overby G, Sher G. The Graduated Embryo Score (GES) predicts blastocyst formation and pregnancy rate from cleavage-stage embryos. Hum Reprod 2001;16:1970-5.

24. Lechniak D, Pers-Kamczyc E, Pawlak P. Timing of the first zygotic cleavage as a marker of developmental potential of mammalian embryos. Reprod Biol 2008;8:23-42.

25. Bromer JG, Seli E. Assessment of embryo viability in assisted reproductive technology: shortcomings of current approaches and the emerging role of metabolomics. Curr Opin Obstet Gynecol 2008;20:234-41

26. Roseboom TJ, Vermeiden JP, Schoute E, Lens JW, Schats R. The probability of pregnancy after embryo transfer is affected by the age of the patient, cause of infertility, number of embryos transferred and the average morphology score, as revealed by multiple logistic regression analysis. Hum Reprod 1995;10:3035-41. 
27. Bassil S, Wyns C, Toussaint-Demylle D, Abdelnour W, Donnez J. Predictive factors for multiple pregnancy in in vitro fertilization. J Reprod Med 1997;42:761-6.

28. Terriou P, Sapin C, Giorgetti C, Hans E, Spach JL, Roulier R. Embryo score is a better predictor of pregnancy than the number of transferred embryos or female age. Fertil Steril 2001;75:525-31.

29. Sakkas D, Percival G, D’Arcy Y, Sharif K, Afnan M. Assessment of early cleaving in vitro fertilized human embryos at the 2-cell stage before transfer improves embryo selection. Fertil Steril 2001;76:1150-6.

30. Ziebe S, Petersen K, Lindenberg S, Andersen AG, Gabrielsen A, Andersen AN. Embryo morphology or cleavage stage: How to select the best embryos for transfer after in-vitro fertilization. Hum Reprod 1997;12:1545-9.
31. Desai NN, Goldstein J, Rowland DY, Goldfarb JM. Morphological evaluation of human embryos and derivation of an embryo quality scoring system specific for day 3 embryos: a preliminary study. Hum Reprod 2000;15:2190-6.

32. Ertzeid G, Storeng R, Tanbo T, Dale PO, Bjercke S, Abyholm T. Cycle characteristics of day 3 embryo transfers with 4-cell embryos only. J Assist Reprod Genet 2003;20:352-7.

33. Glujovsky D, Blake D, Farquhar C, Bardach A. Cleavage stage versus blastocyst stage embryo transfer in assisted reproductive technology. Cochrane Database Syst Rev 2012:CD002118.

34. Laverge H, De Sutter P, Van der Elst J, Dhont M. A prospective, randomized study comparing day 2 and day 3 embryo transfer in human IVF. Hum Reprod 2001;16:476-80. 